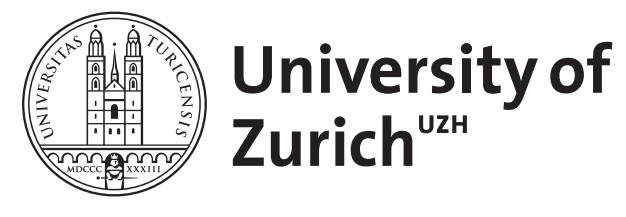

\title{
Politicians: be killed or survive
}

\author{
Torgler, Benno ; Frey, Bruno S
}

\begin{abstract}
In the course of history, a large number of politicians have been assassinated. To investigate this phenomenon, rational choice hypotheses are developed and tested using a large data set covering close to 100 countries over a period of 20 years. Several strategies, in addition to security measures, are shown to significantly reduce the probability of politicians being attacked or killed: extended institutional and governance quality, democracy, voice and accountability, a well-functioning system of law and order, decentralization via the division of power and federalism, larger cabinet size and a stronger civil society. There is also support for a contagion effect
\end{abstract}

DOI: https://doi.org/10.1007/s11127-011-9908-6

Posted at the Zurich Open Repository and Archive, University of Zurich ZORA URL: https://doi.org/10.5167/uzh-155886

Journal Article

Published Version

Originally published at:

Torgler, Benno; Frey, Bruno S (2013). Politicians: be killed or survive. Public Choice, 156(1-2):357-386. DOI: https://doi.org/10.1007/s11127-011-9908-6 


\title{
Politicians: be killed or survive
}

\author{
Benno Torgler · Bruno S. Frey
}

Received: 12 April 2010 / Accepted: 16 December 2011 / Published online: 5 January 2012

(C) Springer Science+Business Media, LLC 2012

\begin{abstract}
In the course of history, a large number of politicians have been assassinated. To investigate this phenomenon, rational choice hypotheses are developed and tested using a large data set covering close to 100 countries over a period of 20 years. Several strategies, in addition to security measures, are shown to significantly reduce the probability of politicians being attacked or killed: extended institutional and governance quality, democracy, voice and accountability, a well-functioning system of law and order, decentralization via the division of power and federalism, larger cabinet size and a stronger civil society. There is also support for a contagion effect.
\end{abstract}

Keywords Assassinations · Rational choice · Governance · Democracy · Dictatorship · Deterrence $\cdot$ Protection

JEL Classification $\mathrm{D} 01 \cdot \mathrm{D} 70 \cdot \mathrm{K} 14 \cdot \mathrm{K} 42 \cdot \mathrm{Z} 10$

\section{Introduction}

On 22 November 1963, news of President John F. Kennedy's assassination shocked the whole world. The murder of politicians and other noted persons has been an important

B. Torgler

The School of Economics and Finance, Queensland University of Technology, GPO Box 2434,

Brisbane, QLD 4001, Australia

B. Torgler · B.S. Frey

CREMA-Center for Research in Economics, Management and the Arts, Gellertstrasse 18, 4052 Basel, Switzerland

B.S. Frey $(\bowtie)$

Department of Economics, University of Zurich, Wilfriedstrasse 6, 8032 Zurich, Switzerland

e-mail: bsfrey@iew.uzh.ch

B.S. Frey

Warwick Business School, The University of Warwick, Scarman Road, Coventry, CV4 7A1, UK 
topic in history. The assassination of rulers and other politicians has been extensively discussed in the historical literature (e.g., Hudson 2000; Demandt 2000; Kellerhoff 2003; von Uthmann 2004). There is also a substantial literature on the assassination of specific politicians (e.g., Woolf 2006 on Caesar, Warren et al. 1964 on John F. Kennedy, or Bondeson 2005 on Olof Palme). It is, of course, a central issue in criminology (e.g., Siegel 2005, 2007; Adler et al. 2006; Schmalleger 2004). As for the social sciences, the issue has received limited attention in sociology (e.g., Wilkinson 1976) and political science (e.g., Feierabend et al. 1971; Laucella 1999; Barkan 2005, and most importantly Iqbal and Zorn 2006, 2008). There is also a specialized "assassination science" (e.g., Fetzer 2000). However, there are only a few studies in economics dealing directly with political assassinations. The most important contributions include the econometric analysis by Jones and Olken (2009) regarding the consequences of assassinations on institutions and war, and the study by Zussman and Zussman (2006) on the effectiveness of counterterrorism policy on the stock market (see also the more general studies by Frey 2007a, 2007b). The work conducted on the economics of crime (e.g., Becker 1968, 1974) and terrorism (e.g., Enders and Sandler 2006; Frey 2004) is also directly relevant. This article develops and tests empirically a broad set of hypotheses to explore the determinants of actual and attempted assassinations using a large data set, covering 20 years and close to 100 countries. The theoretical approach is developed using a rational choice framework (Sect. 2). Section 3 introduces the data and econometric model, Sect. 4 presents the empirical results, and Sect. 5 concludes.

\section{Theoretical foundation}

Political assassinations are not uncommon. Politicians are killed in many different circumstances, for example by political enemies seeking revenge. In 1961, the assassination of the first president of the Republic of Congo, Patrice Lumumba, was arranged by his contender Mobutu Sese Seko and, in 2006, the Shiite-Kurdish government ordered the death of the former Sunnite dictator of Iraq, Saddam Hussein. There are also so-called "targeted killings" arranged by other nations (see, e.g., Zussman and Zussman 2006; Statman 2004). There are still a significant number of political assassinations, even if the number recorded is restricted to politicians in power (such as kings, presidents or prime ministers), ${ }^{1}$ to successful attempts, and to those undertaken by one or a few persons. ${ }^{2}$ Famous instances ${ }^{3}$ in classical European antiquity are the assassinations of the Athenian ruler Hypparkos (514 BC), the father of Alexander the Great, Phillip II of Macedonia (336 BC), Cajus Julius Caesar (44 BC),

\footnotetext{
${ }^{1}$ This does not include several recent and significant assassinations, such as Robert Kennedy (1968), Martin Luther King (1968), Rajiv Gandhi (1999), or Piet Fortuyn (2002).

${ }^{2}$ The Latin word "attentatum" (i.e., attempted crime), which still exists today in several languages (e.g., in French "attentat", in Italian "attentato", in Spanish "attentado" or in German "Attentat"), but is not used in English, captures this aspect. Another term sometimes used is "tyrannicide", meaning the killing of a tyrant. The word assassination refers to the Ismaili Muslim sect Hashshahin, or Assassins who, between the $8^{\text {th }}$ and $14^{\text {th }}$ centuries, terrorized the Abbasid elite by fearlessly executing the politically motivated murders of rulers.

${ }^{3}$ Facts on political assassinations have been taken from various sources (especially Iqbal and Zorn 2006, 2008; and Jones and Olken 2009). Various articles in Wikipedia on "Assassination", "List of assassins", "List of unsuccessful assassinations", "List of assassinated people", "List of people who survived assassination attempts", "List of assassinations by car bombing", "List of assassinated anticolonialist leaders" were also useful; the information reported there was double-checked.
} 
and a large number of Roman Emperors. ${ }^{4}$ Political assassinations seldom occurred in Medieval Europe (though the French Kings Henry III and Henry IV were killed in 1589 and 1610, respectively). More recent times saw many such murders. Four American presidents have been assassinated (Abraham Lincoln 1865, James A. Garfield 1881, William McKinley 1901, and John F. Kennedy 1963). In Russia, the four emperors Ivan VI, Peter III, Paul I and Alexander II were murdered in less than 200 years. The post-war period of the $20^{\text {th }}$ century has also seen a large number of political assassinations, attracting massive media attention. In addition to John F. Kennedy in 1963, other notable persons include the Spanish Prime Minister (PM) Luis Carrero Blanco in 1973, the Egyptian president Anwar al-Sadat in 1981, the Indian PM Indira Ghandi in 1984, the Swedish PM Olof Palme in 1986, and the Serbian PM Zoran Djincjic in 2003.

\subsection{A Public Choice approach to political assassinations}

In Schumpeter's (1942) and Downs' (1957) model of perfectly competitive democracy, the two parties offer the same program. If one party leaves office, the contending party pursues the same program at the median of citizens' preference distribution. Hence, there is no incentive to kill a party leader, as this would not change policy. Assassinations of politicians in power would not be necessary and politicians would not need to be protected against would-be assassins. However, the previous sub-section has shown that such an approach cannot explain the large number of political assassinations. It is therefore useful to reconsider a theoretical framework that helps to deal with the determinants of assassinations. The simple approach we suggest has its foundation in the economic theory of crime initially developed by Becker (1968, 1974), which has since been extended and empirically tested on several occasions (see, e.g., Alper and Hellman 2006; Cameron 1988), and has been applied to political assassinations (Frey 2007b). Similar approaches have also been used to model rational extremism (Wintrobe 2006).

\subsection{Testable propositions}

The following aspects are expected to determine the level of actual and attempted assassinations:

\subsubsection{Catching potential attackers}

There are many different countermeasures designed to deter political assassinations. The more resources devoted to policeman, court personnel, and specialized equipment, the easier it is to discover offenses and convict offenders. The more developed the state of detection technologies, the easier it is to achieve a higher level of success (Becker 1968). We control for these factors empirically, using defense and, alternatively, police expenditures, as proxies.

An efficient deterrence process is also generated by a better legal system. We therefore introduce a law and order variable that assesses the strength and impartiality of the legal system and the popular observance of the law. This leads us to the first hypothesis:

\footnotetext{
${ }^{4}$ Just to name a few: Caligula (41 AD), Claudius (54), Vitellius (69), Galba (69), Domitian (96), Commodus (192), Didius Julianus (193), Geta (212), Caracalla (217), Elagabal (222), Maximinus Thrax (238), Pupenius (238), Balbinus (238), Volasianus (253), and Galeus (253).
} 
H1 An increase in the efforts to apprehend and convict assassins reduces the probability of (attempted) assassinations.

One can argue that assassinations are contagious (Iqbal and Zorn 2006). The economic literature on crime has stressed that the prevalence of a given type of such behavior in the past may change the propensity of others to engage in the same behavior. It affects the perceptions about the net return to criminal acts (information function) and also the probability of arrests or constraints (Ludwig and Kling 2006; Cook and Goss 1996; Becker and Murphy 2000; Manski 1993, 2000). A larger number of previous assassinations are an indicator that the government is not able to cope efficiently with assassins.

H2 Due to contagion effects, the current number of (attempted) assassinations depends positively on the number of previous (attempted) assassinations.

In contrast, if the level of protection is positively related to assassination attempts in the past the current number of attempts is related negatively to that variable.

\subsubsection{The probability of a successful assassination and/or the required effort to assassinate a ruler}

The better a politician is protected against would-be killers, the larger are the costs for the attacker. In history, there are prominent examples of organizations established to protect politicians. ${ }^{5}$ One of the earliest and best known is the Praetorian Guard ("Praetoriani") used by the Roman emperors. It dates back at least to the Scipio family and existed until 275 AD when it was dissolved by Constantine I. The size of this guard varied over time. Under the first emperor Augustus, it was quite large, consisting of 9 cohorts of 500 to 1,000 men each. After Augustus, the praetorians started to meddle in political affairs. Instead of protecting emperors, they often killed them, examples being Claudius (54 AD), Galba (69), Vitellius (69), Pertinax (193), Caracalla (217), or Elagabalus (222).

The Janissaries formed the Ottoman sultan's household troops and bodyguard. It originated in the $14^{\text {th }}$ century and was abolished 400 year later (1826) by Sultan Mahmud II. Its full strength varied widely. In 1475 , for example, it numbered 6,000 men, and in the $18^{\text {th }}$ century it numbered 113,000 men (Nicolle 1995). As was the case with the Praetorians, the Janissaries meddled heavily in politics and also killed rulers they were supposed to protect, one of whom was Sultan Osman II in 1622.

The Garde Impériale was established in 1799 to protect the French consuls, but gained prominence under Emperor Napoléon. It consisted of the most prominent Old Guard, the Middle Guard and the Young Guard. In 1804, it numbered 8,000 men, but with the invasion of Russia in 1812 it comprised more than 100,000. Their final defeat was at Waterloo, where they retreated despite their motto "La Garde meurt, mais il ne se rend pas".

Hitler's bodyguard considered themselves the $20^{\text {th }}$ century equivalent of the praetorians (but they were loyal to the Führer until the very end of WWII). The Schutzstaffel SS (Höhne 1979; Graber 1982) was established in 1920 as a personal guard for Hitler. Until 1929, it numbered no more than 280 personnel, but under the leadership of Heinrich Himmler it grew to 52,000 men in 1932, to 250,000 men by the beginning of the war, and comprised 38 divisions during the war. Hitler's personal security (see Hoffmann 1980) was, of course,

\footnotetext{
${ }^{5}$ See, e.g., Melanson and Stevens (2005), Beyer (2003), DiJulius (2003). The following articles in Wikipedia proved helpful in gaining an overview: "Bodyguard", "Praetorian Guard", "Janissary", "Imperial Guard", "United States Secret Service", "Royalty and Diplomatic Protection Department".
} 
a smaller unit. In 1934, it was the Leibstandarte SS Adolf Hitler (LSSAH), but when this unit engaged in battle as part of the Waffen-SS in the War, Hitler's personal security was entrusted to the Reichssicherheitsdienst RSD.

Today's most prominent bodyguard is in the United States. It has been designed to protect the president and comprises 2,100 plainclothes special agents (usually in conservative business suits, sunglasses and communication earpieces), a uniformed division of 1,200 persons and 1,700 technical and administrative employees. ${ }^{6}$ The corresponding unit in the United Kingdom is called the Royalty and Diplomatic Protection Department, and in Russia it is the Federal Protective Service (Deriabin 1984; Deriabin and Bagley 1990). The latter is estimated to number more than 30,000 uniformed personnel plus several thousand plainclothes agents. Bodyguards can sometimes be disloyal. A famous case is the assassination of the Indian Prime Minister Indira Gandhi in 1984 by two of her Sikh bodyguards (Frank 2002; Sarin 1990; Dilip and Ashok 1985).

The preceding discussion of the various bodyguard units highlights the impossibility of getting any clear quantitative notion of their size. This is not only due to the fact that much of the work they do is highly secret, but also that they perform many different tasks in addition to protecting the ruling politician. A common feature, however, is that the bodyguard has a strong tendency to grow in leaps and bounds, and that the strict task of protecting the ruler is transferred to a smaller specialized unit. Their growth does not necessarily mean that the ruler is better protected, because their larger sizes and critical responsibilities offer them chances to meddle in politics, and even seize power.

There are many different methods by which it is possible to raise the costs of attacking a politician. The most important ones are: clearing large areas (for instance, shutting down entire sections of cities and roads and restricting access to buildings); using armored cars (of which the best known is the "Popemobile" with its bulletproof glass); using bomb and weapon detectors; wearing bullet proof vests; having a body double as a decoy; or going into seclusion. These counter-measures offer varying degrees of effectiveness, depending on the circumstances, and impose different costs on the person requiring protection. They all serve to make an attack more difficult, raising the cost of attempting to assassinate a politician. We therefore test the following hypotheses empirically:

H3 An increase in protection reduces the number of (attempted) assassinations.

As argued above, we use defense expenditure in relation to total national expenditures and the police budget as a proxy for protection. In addition, law and order can also affect the level of protection.

\subsubsection{Political accountability}

Assassinations of political rulers are undertaken for many different reasons, ranging from political and ideological differences to wanting to attract media attention to the grievances of mentally deranged persons. While leaders of democratic countries are also targets, there seems to be a clear prevalence in dictatorial and authoritarian countries (see KurrildKlitgaard 2000; Tullock 2002; Frey 2011). For example, between 1921 and 1945, there were around 40 assassination attempts on Hitler, ${ }^{7}$ the most notable being by Kurt Lutter in

\footnotetext{
${ }^{6}$ The American Secret Service also investigates a wide variety of financial fraud crimes and identity thefts and provides forensic assistance for some local law-enforcement bodies. Not all of the 5,000 Secret Service agents are directly involved directly in protecting the president.

${ }^{7}$ Duffy and Ricci (1992), Hamerow (1997) and Gisevius (1998).
} 
1933, by Johannes Georg Elser in 1933, by Erwin von Witzleben in 1941, by Henning von Treskow in 1943 and by Claus Schenk Graf von Stauffenberg in 1944. This highlights a central hypothesis in the paper: The more accountable and democratic is a government, the lower the incentives to seek a policy change by exerting force. Interestingly, in Switzerland (a country with highly developed institutions of direct democracy and local autonomy), the Swiss politicians, including the members of the Bundesrat (the Federal Council), are not normally protected and take pride in using the same public transportation services as everyone else. Indeed, no member of the Federal Council has ever been killed for political reasons. ${ }^{8}$

Conversely, there is a strong desire to kill rulers and politicians who impose their wills on the population. The less accountable a ruler is, i.e., the more he or she pursues his or her own goals and disregards those of the population, and oppresses them, the greater is the benefit gained by killing him or her. In contrast, in a politically accountable state, this incentive is weak, because policies are more likely to take into account the preferences of the population. Moreover, the rulers are sanctioned by an elected parliament that is perceived to be efficient, or in some cases even by popular vote. We therefore hypothesize:

H4 Increases in political accountability, government effectiveness and constitutional strength, and therefore an increase in the legitimacy of the ruler(s), reduces the number and the probability of (attempted) assassinations. The stronger the civil society, the fewer politicians are killed.

\subsubsection{Expected gains of killing a ruler}

The expected effect on policy of an assassination (see also Jones and Olken 2009) is greater when there is one politician in charge than if the policy is determined by a committee of (roughly equal) politicians. This one person in charge (it may be a king, a president or a prime minister), plays a prominent role and has some discretion to act according to his or her preferences. He or she therefore becomes the object of dislike or hatred by a number of individuals, some of whom may demand that the ruler be killed. On the other hand, if the government has many cabinet ministers, it will be more difficult to pursue an extreme policy because it is necessary to accommodate various different interests.

Individuals may have an incentive to kill a politician to create chaos, independent of whether the ruling politician responds to the preferences of the majority. This was the avowed goal of some revolutionaries of the 1960s. ${ }^{9}$ However, the probability that a political assassination leads to chaos is smaller in a democracy than in a more authoritarian system, because the succession rules are clearly pre-determined. Therefore, the desire to kill politicians depends on factors similar to those involved when an attacker directly seeks a change of policy. We therefore test the following hypothesis empirically by using cabinet size as a proxy for the number of politicians in charge.

H5 An increase in the number of politicians in charge leads to a decrease in the number of (attempted) assassinations.

\footnotetext{
${ }^{8}$ There have been political assassinations in Switzerland, but the targets have been foreigners visiting or seeking refuge in the country, and the attackers have also been foreigners. Examples are the Austrian Empress and Queen of Hungary Elisabeth ("Sisi" or "Sissi" in books and films), who was killed in 1898 by an anarchist in Geneva, and Kazem Radjavi, representative of the Iranian Resistance to the Commission on Human Rights, who was assassinated in 1990 in Coppet, near Geneva.

${ }^{9}$ It is debatable whether the groups active then meet the conditions outlined above for a political assassination, as these revolutionaries were often terrorist groups (such as the German RAF, the Italian Brigate Rosse, or the French Action Direct) and not one or a few individual attackers (see, e.g., Frey 2004).
} 
In a centralized state, the ruler has more power than in a governmental system with several decision makers. In a country with an extensive division of power between the legislature, the executive and the judiciary, as well as between the central and sub-central units (states, provinces, communes), there is less incentive to kill politicians because the advantages of assassinating leading politicians is expected to be smaller.

H6 The more centralized a country is, the more assassinations are observed.

On the other hand, more political instability/unrest or civil conflict raises the number and the probability of (attempted) political assassinations. An increase in the level of popular discontent makes it harder for the rulers to satisfy citizens' preferences, which can lead to an increase in (attempted) assassinations. Assassinations are fostered by the presence of more generalized political unrest, and people may feel the need to engage in all kinds of political violence, including assassinations (Iqbal and Zorn 2006).

H7 An increase in the level of political instability and unrest (conflicts) raises the number of (attempted) assassinations.

Greater income inequality also reduces trust in the ruler(s). It is an indicator of less solidarity by elites with lower income groups. Furthermore, income inequality may be associated with political instability. On the one hand, less privileged groups may choose undemocratic means to improve their situation (Alesina and Perotti 1996). On the other hand, privileged groups may try to maintain their position by illegal means.

H8 More income inequality increases the number and the probability of (attempted) assassinations.

The more developed the media, the more attention is focused on the ruler. An important part of any dictator's policy is using the media to his or her advantage (see Glaeser 2006). Hitler was one of the first to fully exploit this possibility (skillfully managed by Goebbels, see, e.g., Fest 1963; Kershaw 2000); contemporary dictatorships do the same, sometimes to an extreme (as in the case of Saparmurat Niyazov, President of Turkmenistan 1985-2006, or Kim Jong-il in North Korea). The downside of the dictator's personality cult is that much attention is focused on his or her person, making him or her the object of aggression (e.g., Reiner 2002). On the other hand, greater freedom of the press can reduce the probability of (attempted) political assassinations. Freedom of speech and freedom of the press are generally considered to be important human rights and are powerful controls against government malfeasance (Brunetti and Weder 2003), providing alternative ways of achieving political changes or expressing political preferences. We focus using Freedom House data on the absence of press freedom by looking at repressive actions (e.g., killing of journalists, physical violence against journalists, arrests, harassment, self-censorship). Repression reduces the ability of the populace to have a "voice", which reduces the possibilities and incentives for using legal pressure and increases the incentives to gain from violent political change.

H9 Reducing freedom of the press, in the form of media repression, increases the incentive for political assassinations.

It may be argued that some would-be assassins want to attract the attention of the media by killing a ruler; they are not interested in the political consequences. With a free press, the attention gained is typically greater in an open society than in an authoritarian system, where the news may even be suppressed so that the political class can cling to power. A recent example was the sudden death of the dictatorial ruler of Turkmenistan, Niyazov. It was rumored that he was poisoned, but whether that is true or not remains unclear, as the media 
are completely controlled. In contrast, in a country with free media, such rumors cannot be suppressed, which raises the public attention drawn by a political assassination. Thus, there may also be an imitation effect brought about by intensive media attention (Reiner 2002; Christensen 2004).

\section{Data and econometric model}

\subsection{Political assassinations}

A POLITICAL ASSASSINATION (PA) is defined as "any politically motivated murder or attempted murder of a high government official or politician". The Banks' Cross-National Time-Series Data Archive ${ }^{10}$ supplies the data, which covers a large set of countries over a very long period of time. Tables A.1 and A.2 and Fig. A.1 provide an overview of the data analyzed herein. Nevertheless, it should be noted that the data are not bias-free. Many aspects of political murders are either unknown or uncertain, or for political reasons remain undisclosed. Moreover, in the case of political assassinations, the data are often not objective but are systematically manipulated by the persons and organizations involved. This applies in particular to thwarted assassination attempts. The security services often have an interest in publicizing - or even in inventing - thwarted attempts in order to emphasize their own importance, and thereby to gain more prestige, political support and funding. Under different circumstances, the security services may have an interest in suppressing the publication of such events because they fear an imitation effect. Such manipulation is easier in dictatorships and in countries with controlled media than in developed democratic ones. This means that some of the data points are more unreliable than others. This creates a special problem, because political assassinations seem to occur more often in authoritarian developing economies than in democratic developed economies.

\subsection{Independent variables}

We use the International Country Risk Guide (ICRG) data set to measure political risk, political accountability and law and order. The POLITICAL RISK INDEX $(P R I)$ provides an assessment of the political stability on a comparable basis by using 12 different measures that include both political and social factors. Those measures incorporate factors such as bureaucratic quality, corruption, democratic accountability, government stability, law and order, internal and external conflicts, religious and ethnic tensions, or military presence in politics. ${ }^{11}$ More points indicate less potential risk and therefore higher scores are in line with greater institutional and governance quality. We develop a further index, namely POLITICAL ACCOUNTABILITY $(A C)$ that focuses on five of the ICRG's variables-bureaucratic quality, corruption, democratic accountability, government stability and law and order. In addition, LAW \& ORDER $(L O)^{12}$ is a key explanatory variable in our theoretical model (see previous section). Further data are taken from the Banks' Cross-National Time-Series Data

\footnotetext{
${ }^{10}$ For simplicity's sake, the term "political assassination" is taken to include both attempted and successful political assassinations.

${ }^{11} \mathrm{http}: / /$ www.icrgonline.com/page.aspx?page=icrgmethods\#Background_of_the_ICRG_Rating_System. We are not aware that the overall index covers also political assassinations.

${ }^{12}$ The 'law' sub-component measures the strength and impartiality of the legal system, while the 'order' sub-component is an assessment of popular observance of the law.
} 
Archive, namely cabinet size (CS), which refers to the number of ministers of cabinet rank and several variables that allow us to construct a Conflict Index $(C I)^{13}$ that covers general strikes, guerrilla warfare, government crises, purges, riots, revolutions and anti-government demonstrations. The remaining variables $(C T R L)$ are collected from the World Development Indicators and refer to population size, share of people age 65+, and GDP. To our knowledge, no internationally comparable data on security expenditures and other efforts to protect politicians are available. For the same reason that the number of assassination attempts may be biased, the activities of the security organizations are not revealed. As a (admittedly imperfect) proxy, we take defense expenditures as a percentage of total national government expenditures (derived from the Banks' Cross-National Time-Series Data Archive), because it can arguably be assumed that the two variables are strongly positively correlated. The larger the share of military expenditures, the greater the protection given to politicians is expected to be. In addition, we use the total police budget/financial resources in millions (USD) to get a closer proxy for specific protection of the politicians that is normally conducted by the national or sub-national police forces. We therefore rely on data reported by the United Nations Surveys on Crime Trends and the Operations of Criminal Justice Systems (CTS). The GINI coefficient is used as a proxy for income inequality, using the World Income Inequality Database. A proxy for decentralization and federalism is derived from the DPI 2004 Database of Political Institutions. An index is constructed covering the following variables: contiguous autonomous regions, locally elected municipal governments and state/province governments. ${ }^{14}$ The classification of the countries over time is based on the World Development Indicators database. The data indicates that there is a certain level of time series variation within countries (see, e.g., Fig. A.2).

\subsection{Specifications}

To test our hypotheses, the following baseline equations are estimated:

$$
\begin{aligned}
& P A_{i t}=\alpha+\beta_{1} C T R L_{i t}+\beta_{2} P R I_{i t}+\beta_{3} C I_{i t}+\beta_{4} C S_{i t}+T_{t}+\text { REGION }_{i}+\varepsilon_{i t} \\
& P A_{i t}=\alpha+\beta_{1} C T R L_{i t}+\beta_{2} A C_{i t}+\beta_{3} C I_{i t}+\beta_{4} C S_{i t}+\text { TD }_{t}+\text { REGION }_{i}+\varepsilon_{i t} \\
& P A_{i t}=\alpha+\beta_{1} C T R L_{i t}+\beta_{2} L O_{i t}+\beta_{3} C I_{i t}+\beta_{4} C S_{i t}+T_{t}+\text { REGION }_{i}+\varepsilon_{i t}
\end{aligned}
$$

where $i$ indexes the countries in the sample and $t$ denotes the year (annually, from 1984 through 2003). We control for time as well as regionally invariant factors and time fixed effects, $T D_{t}$, and fixed regional effects, $\operatorname{REGION}_{i},{ }^{15} \varepsilon_{i t}$ denotes the error term. Specification (5) can be extended to include lagged political assassination data (LPA, see specification (6)). This allows us to examine whether there is a contagion effect. Moreover, it provides a way to account for in other ways unobserved historical factors, which are difficult to account for in other way.

\footnotetext{
${ }^{13}$ We use the Weighted Conflict Index provided by Banks' Cross-National Time-Series Data Archive without considering political assassinations. The weighted conflict index is calculated in the following manner: multiply the value of the number of General Strikes by 43 , Guerrilla Warfare by 46 , Government Crises by 48, Purges by 86, Riots by 102, Revolutions by 148 and Anti-Government Demonstrations by 200. Add the weighted values together and divide by eight (see Banks' Cross-National Time-Series Data Archive codebook).

${ }^{14}$ The mean value of all sub-factors.

${ }^{15}$ We differentiate between Europe, Latin America, North America, North Africa, Sub Saharan Africa, the Pacific, Asia, the Caribbean and Australia.
} 


$$
\begin{aligned}
P A_{i t}= & \alpha+\beta_{1} C_{T R L_{i t}}+\beta_{2} L O_{i t}+\beta_{3} C I_{i t}+\beta_{4} C S_{i t} \\
& +\beta_{5} L P A_{i t}+T D_{t}+R_{E G I O N}+\varepsilon_{i t}
\end{aligned}
$$

In further specifications, the number of independent variables can be extended to include GDP per capita. It controls for wealth and economic development, which identifies polities that provide more benefits to the people (Iqbal and Zorn 2006). In addition, we test alternative hypotheses, focusing on further variables (FV), such as the impact of defense expenditures, federalism, lack of freedom of the press and income inequality.

$$
\begin{aligned}
P A_{i t}= & \alpha+\beta_{1} C T R L_{i t}+\beta_{2} L O_{i t}+\beta_{3} C I_{i t}+\beta_{4} C S_{i t} \\
& +\beta_{5} L P A_{i t}+\beta_{6} F V_{i t}+T D_{t}+R_{E G I O N}+\varepsilon_{i t}
\end{aligned}
$$

\section{Empirical results}

Table 1 presents the basic results. We report three models, namely OLS specifications, probit models where 1 measures whether a political assassination happened in $i$ at time $t$ ( 0 otherwise), and left-censored tobit models due to a large number of zeros in the data set. In the OLS estimations, the beta or standardized regression coefficients compare magnitude, revealing the relative importance of the variables employed. To obtain robust standard errors in these estimations, we use the Huber-White-Sandwich estimators of them. Table 1 indicates that the results are quite robust with regard to the chosen models. In the first three specifications, we explore the effect of the POLITICAL RISK INDEX variable. The coefficient is highly statistically significant. The probit specification (see regression (2)) indicates that an increase in the political risk index variable by one unit reduces the probability of assassinations by 2.8 percentage points. In specifications (4) to (6), the variable POLITICAL ACCOUNTABILITY replaces the POLITICAL RISK INDEX. The result suggests that political or governance institutions are important. The coefficient is always statistically significant, showing relatively large quantitative effects. The greater the level of accountability and governance quality, the lower is the incentive to kill politicians, as the preferences of the people are better taken into account in the political process. Thus, an increase in political accountability, government effectiveness and constitutional strength, or, in other words, an increase in the legitimacy of the ruler(s), reduce the number of political assassinations. The stronger the civil society, the fewer politicians are killed (or become victims of assassination attempts). In specifications (7) to (9), we use a sub-factor of these indices, namely LAW AND ORDER instead of POLITICAL ACCOUNTABILITY or the POLITICAL RISK INDEX. The results show that the variable LAW AND ORDER has an even stronger negative impact on political assassinations, as evidenced by the size of the coefficients, the marginal effects and the $R^{2}$. In last three specifications (10) to (12), the variable CONFLICT INDEX is omitted to check for robustness, as it can be argued that variable is endogenous. As can be seen, the previous results remain robust. In particular, we observe that LAW AND ORDER is still statistically significant and indicates the strongest quantitative effects among all of the independent variables entered. We will therefore retain LAW and ORDER as a control variable in the following specifications.

In sum, the findings indicate that hypothesis 1 (on the effort made to apprehend and convict assassins) and 4 (on legitimacy and civil society) cannot be rejected. The CONFLICT INDEX variable is also statistically significant at the $1 \%$ level in all 12 regressions, producing the largest beta coefficients. Thus, an increase in political instability, political unrest or conflicts increases the number and the probability of (attempted) political assassinations 


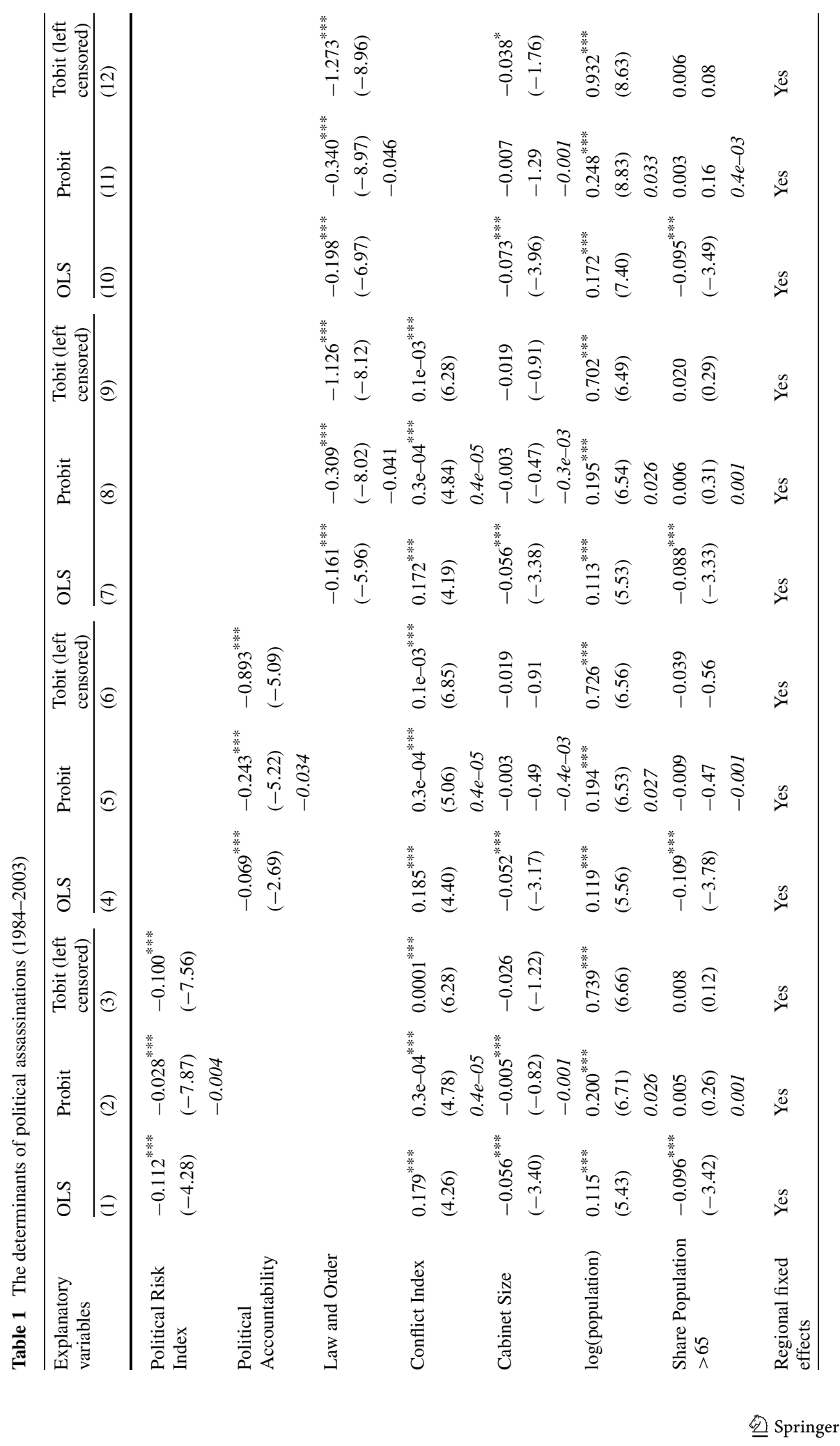




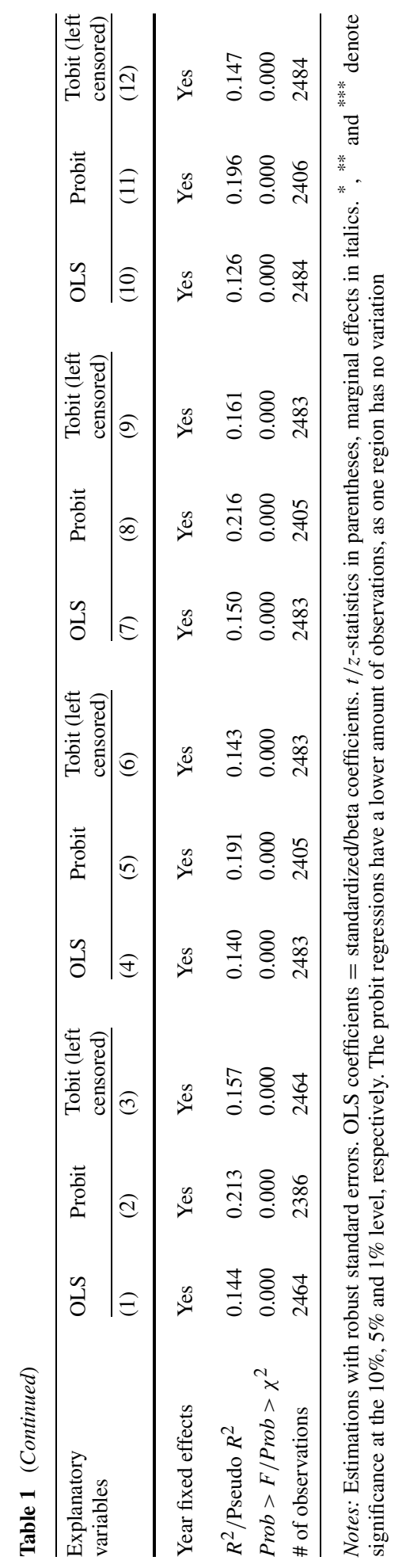


quite markedly, a result that supports hypothesis 7 . This result is consistent with that reported by Iqbal and Zorn (2006).

Table 1 suggests that cabinet size is negatively correlated with political assassinations, which is consistent with hypothesis 5 . A large cabinet reduces the incentives to kill an individual politician. However, compared to the other variables discussed, the effect is not very strong and the coefficient is not always statistically significant in the three models.

In the next step, we explore whether we find a contagion effect and how economic development affects political assassinations. The results are reported in Table 2. The lagged assassination variable (ASSASSINATION $(t-1)$ ) is always statistically significant and shows the largest beta coefficients of all the results reported in Table 2. Contrary to Iqbal and Zorn (2006), we observe a strong contagion effect, which is consistent with hypothesis 2 . The previously observed results remain robust. Specifications (19) to (21) report a positive relationship between economic development and political assassinations. However, the coefficient is statistically significant only in the OLS regression. This suggests that developed countries are not immune from political assassinations, once we control for governance/institutional quality and the level of conflict. ${ }^{16}$

As we rely mainly on cross-sectional variation we also present in Table 3 standard error adjustments where we cluster at the country level to deal with the possible criticism that observations within countries are not independent. First, we present results using the POLITICAL RISK INDEX as a key independent variable (see regressions (22) to (24)). In the next set of regressions we work with the variable LAW AND ORDER (see (25) to (30)). In regressions (28) to (30) we also explore the impact of past assassinations. As can be seen, the previous results remain robust. Although we observe a decrease in the $t$ - or $z$-values, the key independent variables POLITICAL RISK INDEX, LAW AND ORDER and CONFLICT INDEX are statistically significant at the $1 \%$ level. Similarly, the variable ASSASSINATION $(t-1)$ is also highly statistically significant, which provides support for a contagion effect that is not solely due to specific country characteristics. Looking at the control variables we find that population size matters.

Table 4 tests the remaining hypotheses. For simplicity's sake, we report only the coefficients of the variables of interest. Table 4 provides a summary of 20 regressions. The findings show that hypothesis 3 cannot be rejected. An increase in defense expenditures in relation to total national expenditures reduces the number of political assassinations. To the extent that defense expenditures are indeed a reasonably good proxy for the unobtainable expenditures and other efforts to protect politicians, the estimation results indicate that the better a politician is protected against would-be killers, the larger the costs to the attacker and the smaller the number of political assassinations. However, it is possible to criticize this finding on the grounds that protection of politicians is often entrusted to the police. Moreover, control of the domestic territory and maintenance of public order is important to ensuring that politicians are generally safe wherever they travel. We therefore use total police budget/financial resources in millions (USD), and the results also show that an increase in the total police budget reduces political assassinations. The coefficient is highly statistically significant in all four specifications.

Comparable effects are observable when focusing on how decentralization affects political assassinations. The coefficient is also statistically significant in all specifications, with

\footnotetext{
${ }^{16}$ Nevertheless, one should keep in mind the previous discussion with regard to potential biases in our dependent variable. Due to potential manipulation, data from developing countries are less reliable than those from developed countries.
} 


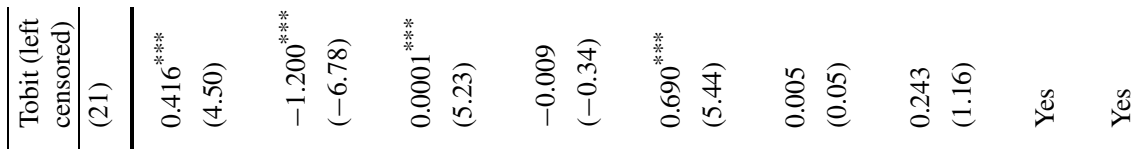

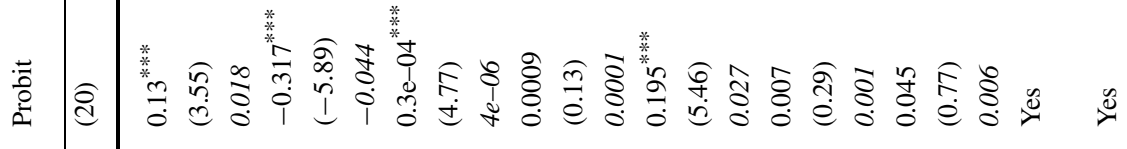

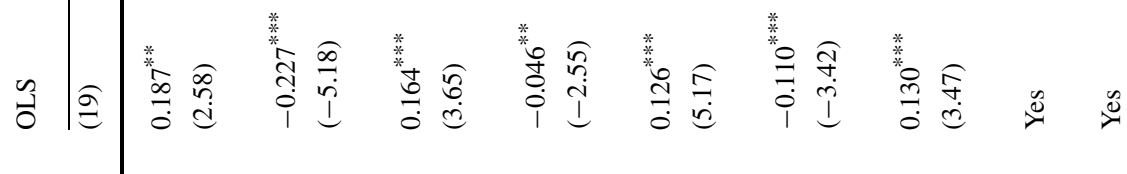

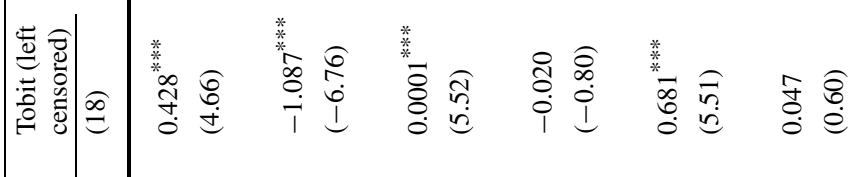

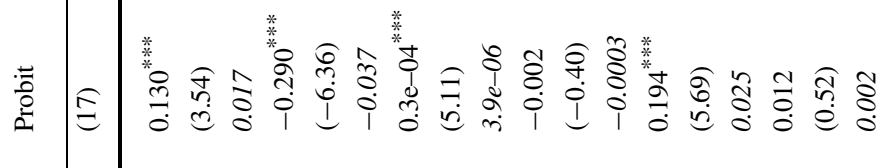

$\succsim$

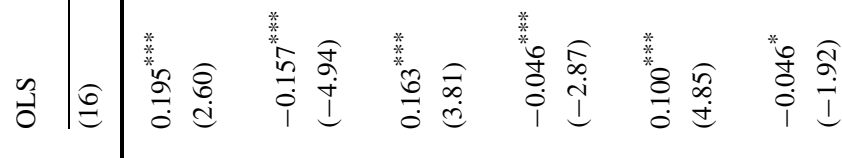

$\succsim$

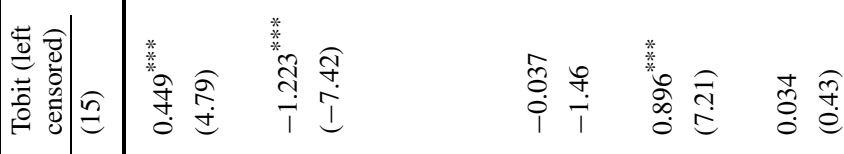

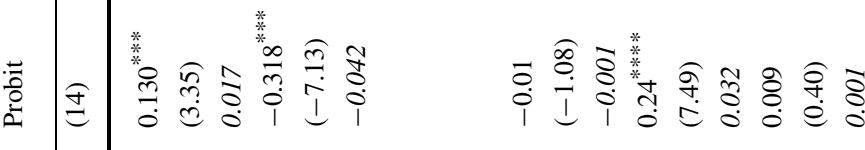

$\overbrace{}^{\infty}$

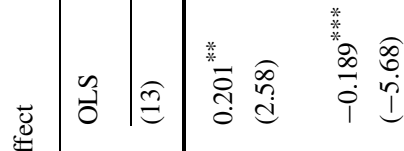

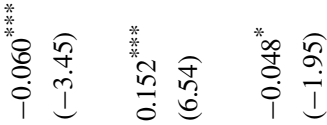

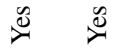




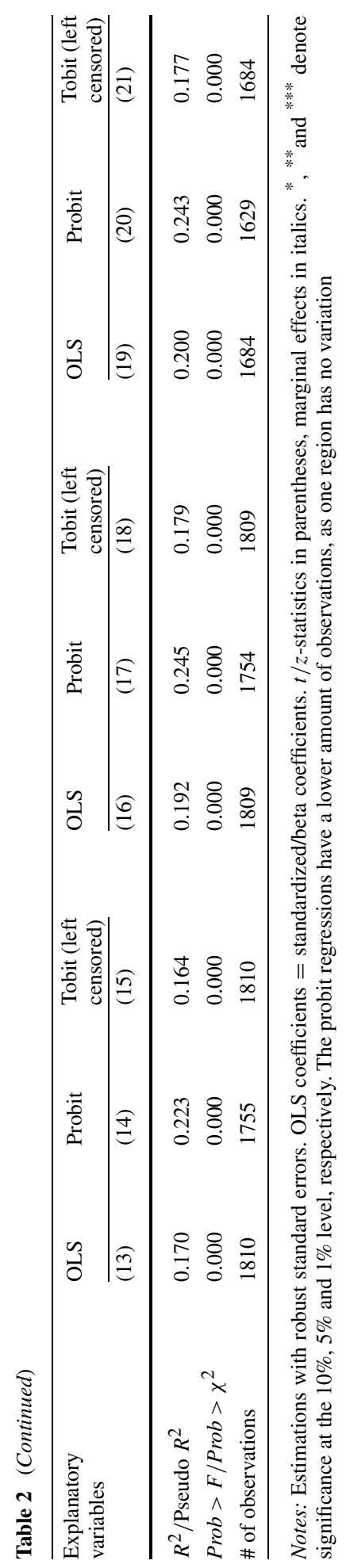




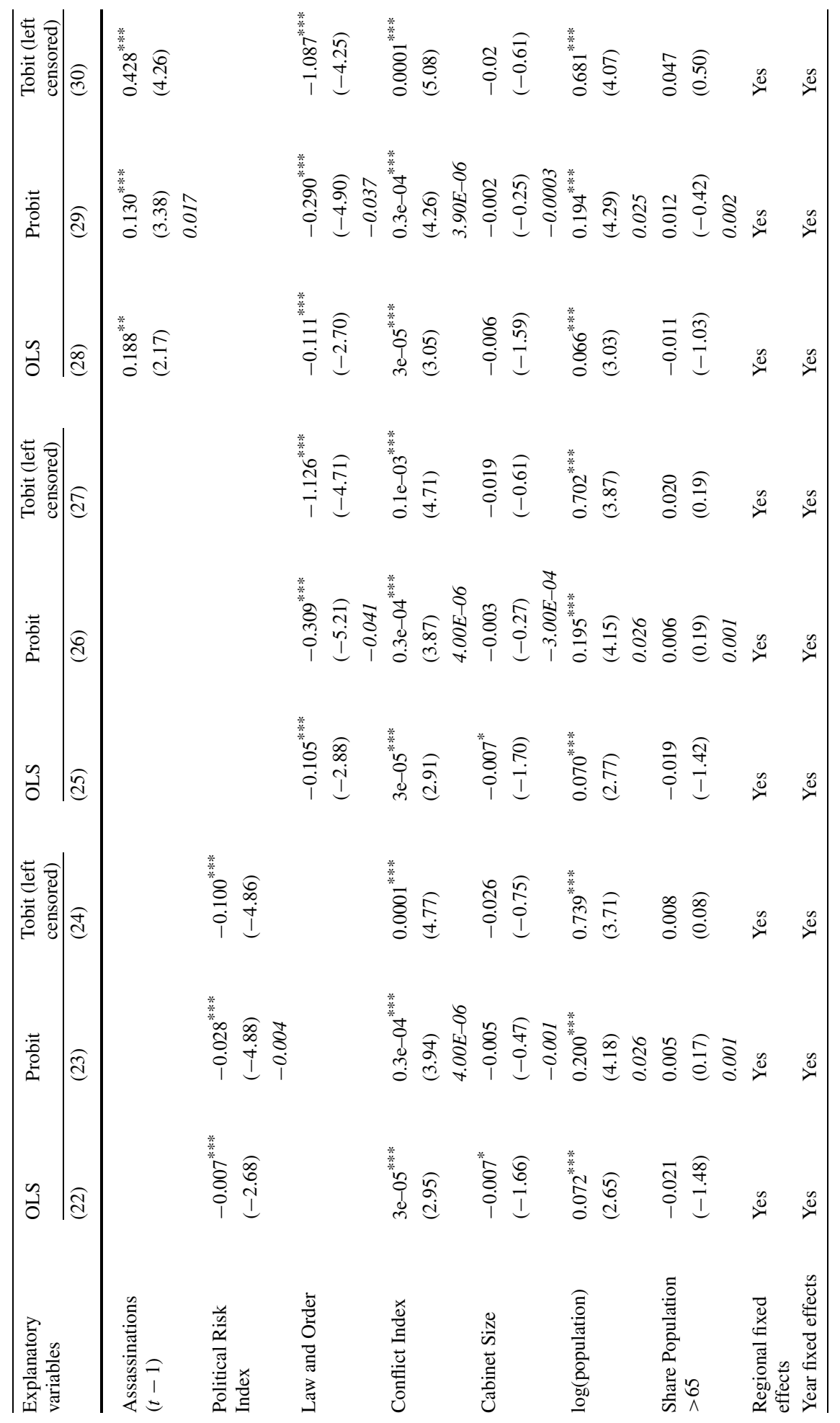




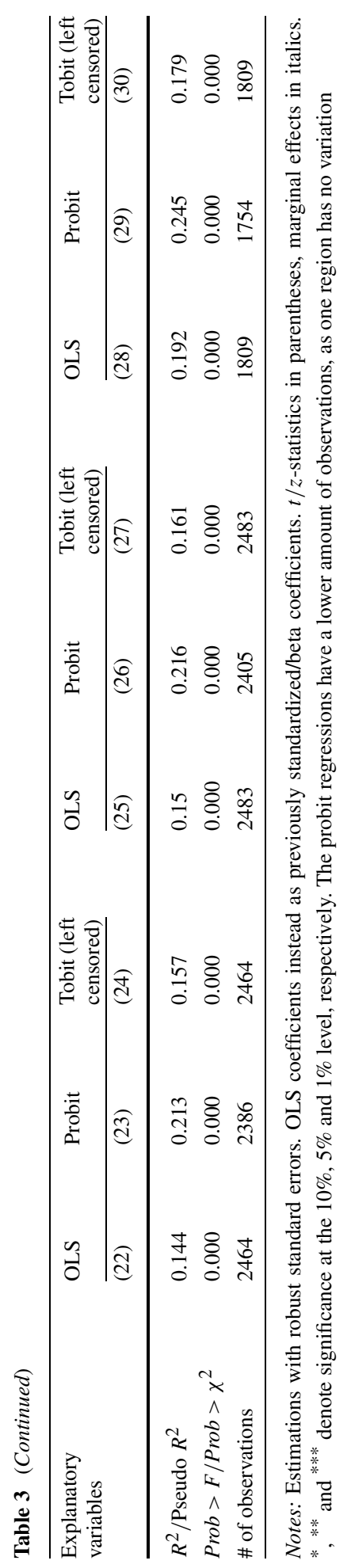




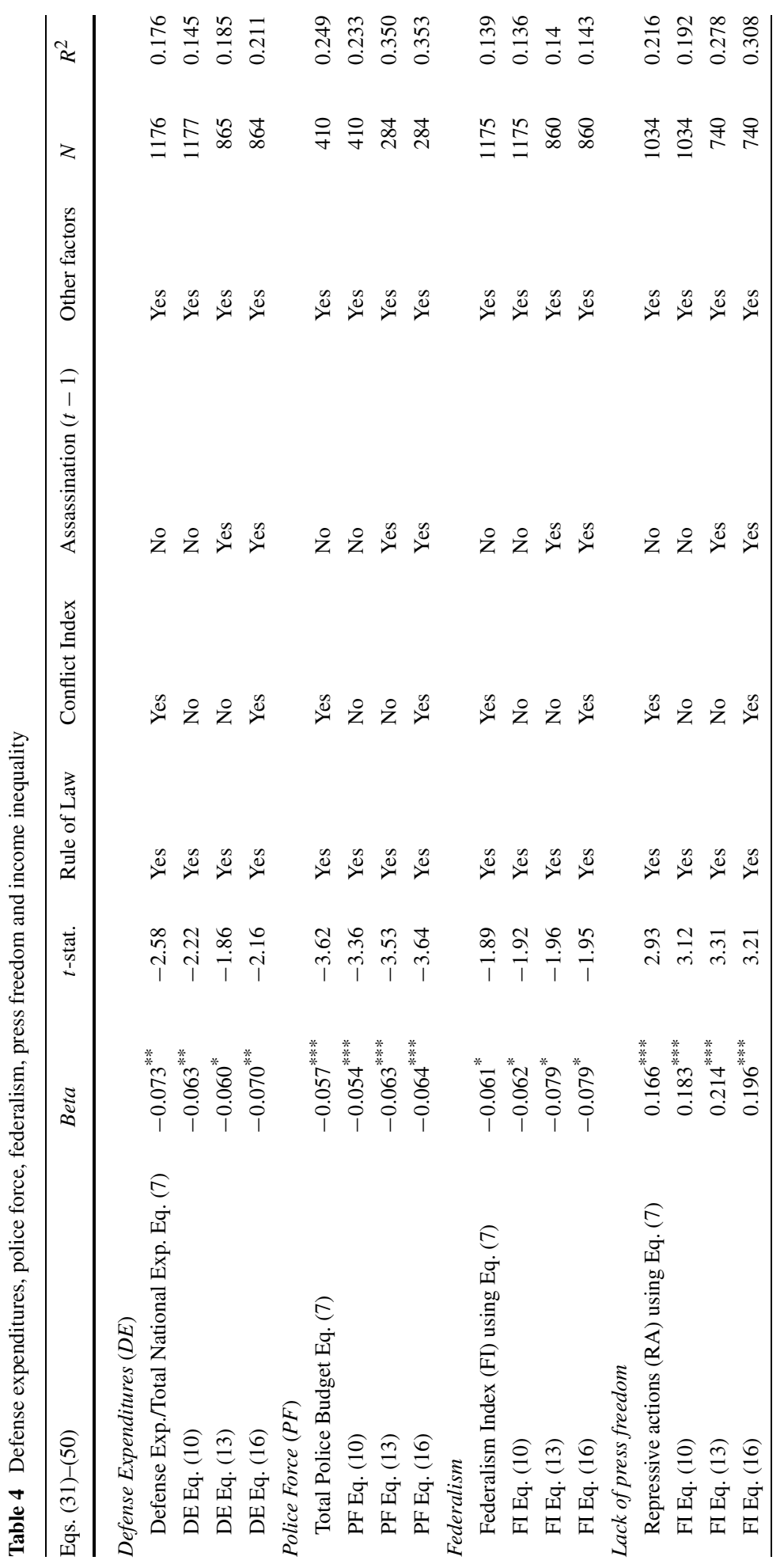




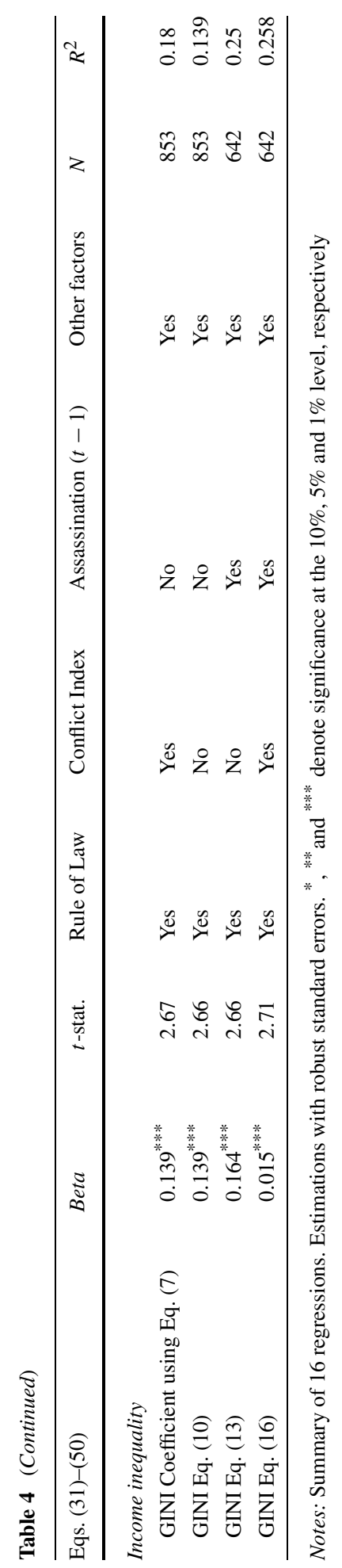


similar beta coefficients. This result is consistent with hypothesis 6. An increase in decentralization through the division of powers and federalism reduces the likelihood of politicians being attacked and killed.

The following regressions focus on the lack of freedom of the press. The findings show a positive correlation with the number of assassinations. This result supports hypothesis $9 \mathrm{Me}-$ dia repression increases the incentive to take radical steps, such as political assassinations, to combat the existing regime. As alternative channels for expressing grievances are suppressed, violent reprisal is encouraged. The coefficient is highly statistically significant and the beta coefficients reveal large quantitative effects. Finally, Table 4 reports how changes in income inequality are related to political assassinations. There is a strong positive correlation that is statistically significant at the $1 \%$ percent level in all the regressions. Thus, hypothesis 8 cannot be rejected. When income is distributed more unequally, the support for the regime in power falls and there is greater incentive to use radical and undemocratic instruments to change the status quo.

We also checked a further variable, namely the total recorded intentional homicides per capita, by again relying on the United Nations Surveys on Crime Trends and the Operations of Criminal Justice Systems (CTS). Including this variable strongly reduces the number of observations as a result of the limited data for all country-years examined. One could argue that where "killing habits" are more developed, the number of persons with the skills to commit homicides is greater while the psychological and ethical constraints on such crimes are looser. Therefore, the chances of succeeding in an attempt to kill political leaders are greater and the cost of trying to kill political leaders as expressed by the variable $E$ (effort level) is lower. Applying the control variables reported in specification 10 indicates a positive correlation between homicides and political assassinations (beta coeff. $=0.037, t$-value: 1.59 ). The coefficient is statistically significant at the $10 \%$ level $(t=1.87)$ if one also controls for conflicts proving standard errors clustering on the country level.

Table 5 checks the robustness of the previous findings by applying an instrumental variables (IV) approach. In a setting where unobserved factors may affect two of the key independent variables (namely governance quality or law and order and conflicts), as well as the political assassinations variable, evaluating the direct effects may require an IV technique to separate the impact of these factors from alternative underlying causes. We therefore move beyond our simple theoretical approach by suggesting potential simultaneity issues. It can be argued that more political assassinations may lead to more conflicts. However, most of the variables included in our index, such as general strikes, anti-government demonstrations, revolutions, or riots can be seen as activities organized by non-elite groups rather than reactions to the existing regime prompted by political assassinations. Jones and Olken (2009) explore whether assassinations affect military conflicts. They find that assassinations have only limited effects on conflict. Successful assassinations lead to an intensification of smallscale conflicts. On the other hand, weaker evidence was found for high-intensity conflicts. Successful assassinations seemed to have the opposite effect, bringing an end to conflict. This may reduce the causality problem. Nevertheless, political assassinations may weaken the current elite, which may provide stronger incentives for seeking a change in power via revolution. For these reasons, it is important to analyze potential causality problems.

Table 5 reports four 2SLS estimations, together with several diagnostic tests and the first-stage regressions. It should be noted that the results remain robust using the variables POLITICAL ACCOUNTABILITY or POLITICAL RISK INDEX, instead of LAW AND ORDER, and using the alternative specifications discussed in previous tables. Table 5 indicates that, for the 2SLS model, the coefficient of our instrumented variables remains statistically significant. Similar results are also visible for other independent variables, such as population or cabinet size. 


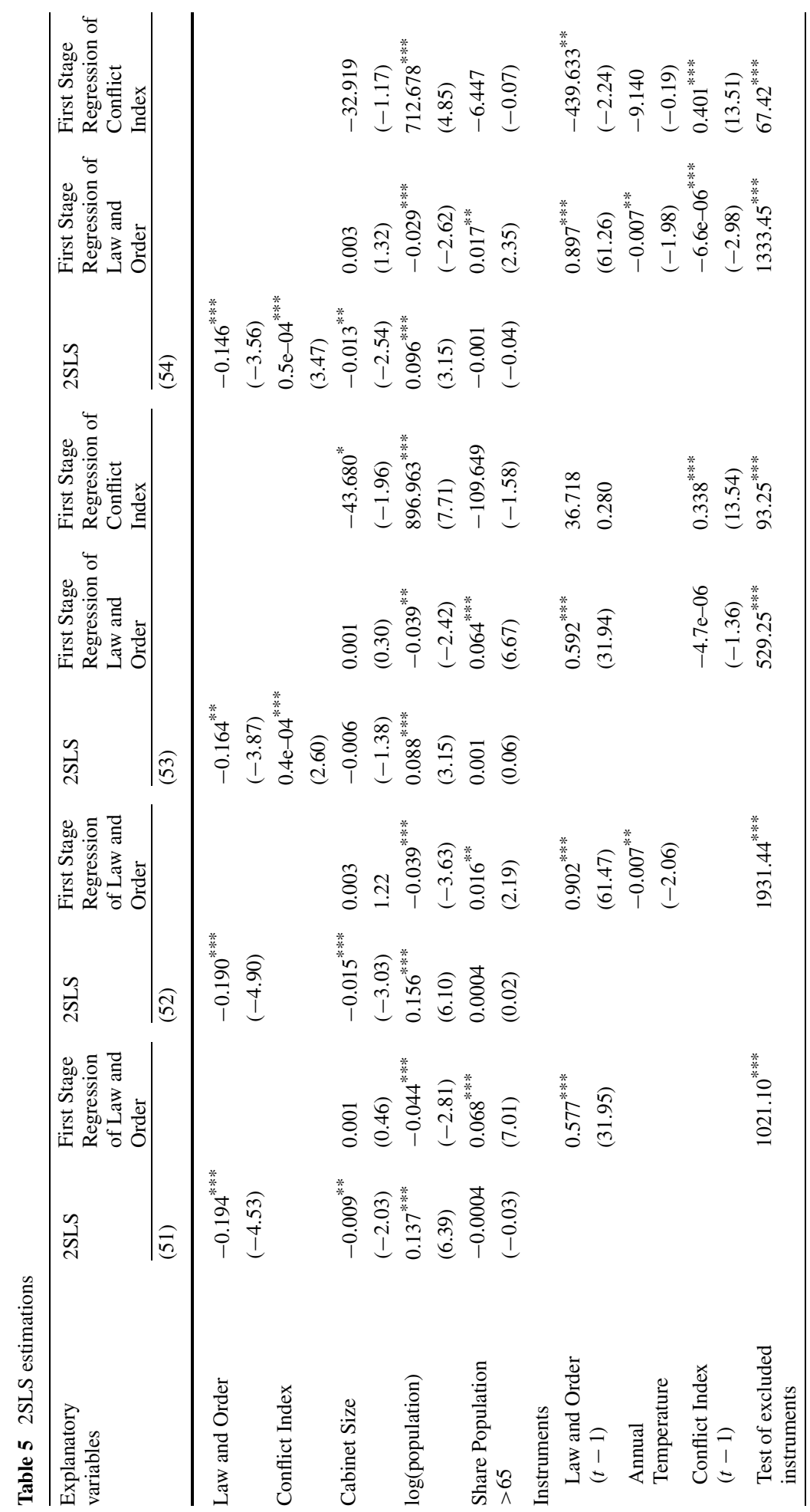




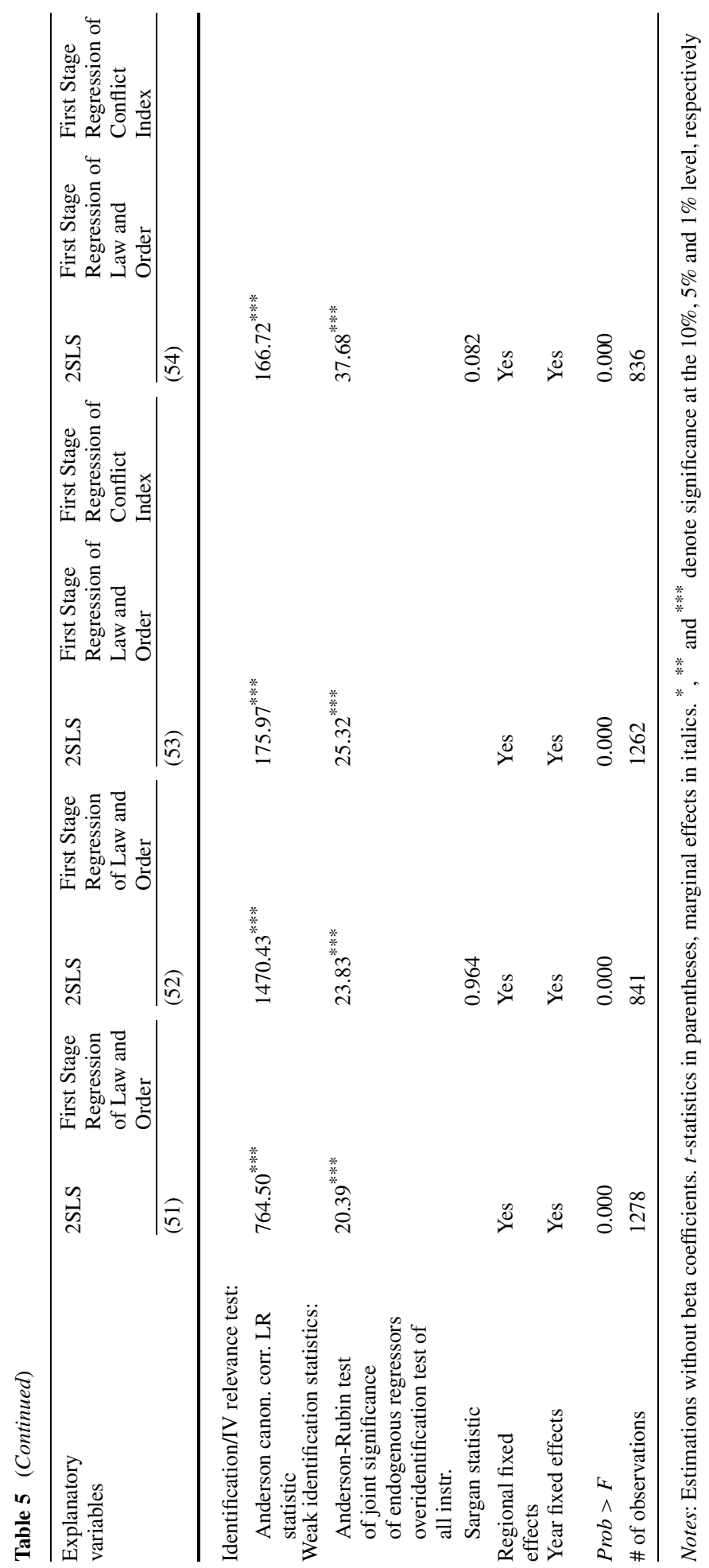


First, we use a lagged law and order variable (LAW AND ORDER $(t-1))$ as a straightforward instrument for LAW AND ORDER (see regressions (47) and (49)). In the next step, another instrument for LAW AND ORDER is added, namely temperature (see regressions (48) and (49)). In the first two regressions in Table 5, the variable CONFLICT INDEX is omitted. Once we include the CONFLICT INDEX, we also include a one-year lagged conflict index variable (CONFLICT INDEX $(t-1)$ ) as an instrument for it (see regressions (49) and (50)). The use of temperature as an instrument requires further discussion. A growing number of studies investigate the way in which climatic conditions have an impact on countries' or regions' institutions (see, e.g., Engerman and Sokoloff 1997; Landes 1998; La Porta et al. 1999; Diamond 1997; Sachs 2000; Hirshleifer and Shumway 2003; Schaltegger and Torgler 2007). Such external factors may affect the characters of inhabitants and, hence, their cultures and institutional arrangements. According to Diamond (1997), geography and climate help to explain different nations' economic destinies. La Porta et al. (1999) investigate the effect of latitude and argue (in line with Landes 1998) that temperate zones are associated with better agricultural conditions and healthier climates, which helps to develop their economies and institutions. However, Sachs (2000:4-5) criticizes this approach, arguing that "when latitude is tested for explanatory power against various direct climate or ecological measures, we find that latitude per se adds little if anything to the explanation of patterns of cross-country development".

The studies of Engerman and Sokoloff (1997), Landes (1998) and Sachs (2000) investigate the connection between climatic zones and economic development. Sachs (2000), for example, presents evidence that production technology in the tropics has lagged behind temperate zone technology in the areas of agriculture and health, which opened a considerable income gap between the climate zones. Roll (1992) emphasizes that unambiguously observable weather is a genuinely exogenous identifying variable. Schaltegger and Torgler (2007), show that weather conditions are valid instruments for government accountability. The advantage of using temperature is that it varies over time to a certain degree. Thus, we investigate the relevance of a nation's annual mean TEMPERATURE in Celsius ${ }^{17}$ as an instrument for LAW AND ORDER, POLITICAL ACCOUNTABILITY and POLITICAL RISK INDEX.

Table 5 shows that the instruments employed are effective in explaining LAW AND ORDER and the CONFLICT INDEX. All factors are statistically significant at the 5\% or $1 \%$ level. Moreover, the $F$-tests for the instrument exclusion set in the first-stage regression are statistically significant at the $1 \%$ level in all cases. Table 5 also reports a test for instrument relevance, using the Anderson canonical correlations LR to analyze whether the equation can be identified. The test shows that the null hypothesis can be rejected, indicating that the model is identified and the instruments are relevant (see Hall et al. 1996). The AndersonRubin test suggests that the endogenous variables are jointly statistically significant. Such a test is robust to the presence of weak instruments. We also present Sargan's (1958) test for over-identification of the specifications (48) and (50), where we use two instruments for LAW AND ORDER to examine the validity of the exclusion restrictions. The test results indicate that the Sargan tests fail to reject the null hypotheses that our instruments are valid. These outcomes support the validity of the instruments employed in the analysis. In sum, the empirical results provided in Table 5 are in line with the results from previous tables, suggesting that the econometric estimation results are consistent with our key hypotheses.

\footnotetext{
${ }^{17}$ See Mitchell et al. (2004).
} 


\section{Conclusions}

In the course of history, many politicians have been assassinated. Even if we count only the murders of rulers, such as presidents, prime ministers, and kings and queens, there are still many cases of such events. These have happened primarily in authoritarian or dictatorial countries, but leaders of democracies have also been targeted, as shown by the many successful assassinations and attempted assassinations of American presidents.

A rational choice analysis is developed to explain the determinants of political assassinations and several hypotheses are tested. The results allow us to draw policy conclusions that go beyond the deterrence approach presently dominating the policy agenda. Our analysis suggests that an extension of voice and accountability, governance quality and rule of law, a larger cabinet, more decentralization via the division of political power and federalism, an increase in freedom of the press, a decrease in income inequality, a strengthening of civil society and an increase in protection significantly reduce the incentive to assassinate politicians.

The results suggest that alternative instruments, going beyond deterrence, should be considered in order to reduce the number of (attempted) political assassinations. The policies presently undertaken are dominated by a deterrence approach, where the costs to the attacker are raised. This is true, even for democracies where more emphasis has been place on protecting politicians by using the secret service, police or military forces. Thus, for example, the security precautions taken to protect the American president are huge, both at home and when he visits foreign countries. ${ }^{18}$ It has become common practice in democratic countries to seal off streets and entire sections of cities to protect local and foreign politicians. The protective measures are even more extensive in authoritarian and dictatorial countries. ${ }^{19}$ However, the costs of these measures are external to these organizations and persons, and are moreover a public bad, so that little, if any, opposition is mustered. The closing off of streets and sections of cities, for example, is costly for the people in terms of inconvenience and time lost. For the secret service, the costs imposed are irrelevant as long as the persons negatively affected have no incentive to oppose them at an individual level. A political movement restricting these measures can easily be thwarted, as the benefits of the security measures are clear.

Quite a different approach to using deterrence is to reduce the expected benefits for assailants. As suggested in our paper, there are a variety of options. A move to a more democratic and accountable regime, a regime with greater governance and institutional quality, with a better functioning law and order system and more power to sub-national units that are less vulnerable to attack members of the executive branch, may reduce the number of (attempted) political assassinations. The decentralization of power can be enhanced by distributing it more equally between parliament and the courts, and by granting more power to the subunits (states, provinces, communes). Policies to reduce income inequality and to promote freedom of the press also tend to reduce the number of political assassinations. In

\footnotetext{
${ }^{18}$ When the US president visits a foreign country, a large number of secret service agents are sent in advance. When the president arrives, he does so with a small air force, a motorcade of armor-plated cars, a communications van packed with state-of-the art devices and 250 heavily armed secret service agents, dozens of advisers and teams of sniffer dogs. See "Protecting the US president abroad" (http://news.bbc.co.uk/2/hi/ amewricas/4535911.stm).

${ }^{19}$ The current emphasis on protective measures can partly be explained by rent seeking (the same can be claimed for the reaction against terrorist threats, treated extensively in Frey 2004, Chap. 2). There are a great many organizations and persons benefiting directly from extended security measures, in particular the secret service community.
} 
addition, changing from one (democratic) ruler (be it president, prime minister or king) to a committee of several persons also reduces the incentive of the assassins to attack executive members. For example, the danger of political assassinations would fall drastically if the US executive were to consist of a committee of equals, say of three to seven persons. The incentive to kill any of them would be much smaller, as any would-be assassin realizes that killing one of them would hardly affect the policy direction.

We also observe that assassinations are contagious. This result is consistent with the criminal literature, which has stressed that the prevalence of a given type of criminal behavior may affect the propensity of others to engage in criminal behavior.

The paper constitutes an empirical step towards deepening the analysis of political assassinations using a large data set. It would have been interesting to check whether our results are robust analyzing successful and unsuccessful assassinations separately as the determinants of the two may differ. Are lone gunmen, for example, more likely to succeed than assassinations attempted by disaffected groups, all else equal? Unfortunately, the used data set does not provide the chance to separate between successful and unsuccessful assassinations. However, that question should be on the agenda for future research. Moreover, we are well aware that an econometric analysis is only one approach to gaining insights into the reasons for political assassinations. Future work could profit from case studies of political assassinations, especially if it were based on the technique of "analytic narratives" (see, e.g., Bates et al. 1998) to generate further theoretical and empirical insights for at least some aspects of the issues involved.

Acknowledgements For advice and suggestions thanks are due to three anonymous referees and one of the Public Choice's Associate Editors and the Editor in Chief William F. Shughart II.

\section{Appendix}

Table A.1 Summary statistics

\begin{tabular}{llllll}
\hline Key Variables & Obs & Mean & Std. Dev. & Min & Max \\
\hline assassinations & 3682 & 0.19 & 0.872 & 0 & 15 \\
political accountability & 2620 & 3.977 & 1.234 & 0.5 & 6.6 \\
law and order & 2620 & 3.646 & 1.545 & 0 & 6 \\
political risk & 2601 & 62.443 & 16.123 & 9.583 & 97 \\
conflict index & 3681 & 2587 & 6123 & 0 & 91125 \\
cabinet size & 3707 & 21.591 & 9.208 & 0 & 109 \\
log(population) & 3709 & 8.301 & 2.288 & 0 & 14.079 \\
share population $>65$ & 3713 & 6.255 & 4.229 & 1.007 & 19.33 \\
log(GDP per capita) & 3442 & 7.495 & 1.551 & 4.035 & 10.751 \\
defense expenditures & 1492 & 0.128 & 0.113 & 0 & 0.819 \\
total police budget & 662 & 648979 & $1.47 \mathrm{E}+07$ & 0.002 & $3.77 \mathrm{E}+08$ \\
federalism index & 1479 & 0.289 & 0.322 & 0 & 1 \\
lack of press freedom & 1487 & 3.094 & 4.085 & 0 & 20 \\
income inequality & 1136 & 37.088 & 10.547 & 16.63 & 73.9 \\
\hline
\end{tabular}


Table A.2 Countries

\begin{tabular}{|c|c|c|c|c|c|}
\hline Albania & $(0.15)$ & Greece & $(0.3)$ & Norway & $(0.00)$ \\
\hline Argentina & $(0.1)$ & Guinea-Bissau & $(0.00)$ & Pakistan & $(0.6)$ \\
\hline Armenia & $(0.417)$ & Guyana & $(0.00)$ & Panama & $(0.15)$ \\
\hline Austria & $(0.026)$ & Hungary & $(0.00)$ & Papua New Guinea & $(0.15)$ \\
\hline Azerbaijan & $(0.333)$ & Iceland & $(0.00)$ & Paraguay & $(0.1)$ \\
\hline Bahrain & $(0.00)$ & India & $(1.35)$ & Peru & $(1.2)$ \\
\hline Belarus & $(0.00)$ & Indonesia & $(0.00)$ & Philippines & (1.412) \\
\hline Belgium & $(0.1)$ & Iran & $(0.35)$ & Poland & $(0.1)$ \\
\hline Bolivia & $(0.15)$ & Iraq & $(0.1)$ & Qatar & $(0.00)$ \\
\hline Brazil & $(0.6)$ & Ireland & $(0.00)$ & Romania & $(0.00)$ \\
\hline Bulgaria & $(0.063)$ & Israel & $(0.35)$ & Russian Federation & $(1.00)$ \\
\hline Canada & $(0.05)$ & Italy & $(0.4)$ & Saudi Arabia & $(0.00)$ \\
\hline Chile & $(0.55)$ & Jamaica & $(0.1)$ & Senegal & $(0.05)$ \\
\hline China & $(0.00)$ & Japan & $(0.1)$ & Slovakia & $(0.00)$ \\
\hline Colombia & $(4.3)$ & Jordan & $(0.00)$ & Slovenia & $(0.56)$ \\
\hline Costa Rica & $(0.00)$ & Kazakhstan & $(0.143)$ & Somalia & $(0.05)$ \\
\hline Croatia & $(0.00)$ & Kenya & $(0.05)$ & Spain & $(0.632)$ \\
\hline Cuba & $(0.00)$ & Korea North & $(0.00)$ & Sweden & $(0.053)$ \\
\hline Cyprus & $(0.00)$ & Latvia & $(0.00)$ & Switzerland & $(0.00)$ \\
\hline Czech Republic & $(0.00)$ & Liberia & $(0.15)$ & Syrian Arab Republic & $(0.00)$ \\
\hline Denmark & $(0.00)$ & Lithuania & $(0.083)$ & Tunisia & $(0.00)$ \\
\hline Dominican Republic & $(0.2)$ & Luxembourg & $(0.00)$ & Turkey & $(0.9)$ \\
\hline Ecuador & $(0.2)$ & Malaysia & $(0.00)$ & Uganda & $(0.05)$ \\
\hline Egypt & $(0.8)$ & Mali & $(0.00)$ & Ukraine & $(0.25)$ \\
\hline Estonia & $(0.00)$ & Mexico & $(1.7)$ & United Kingdom & $(0.05)$ \\
\hline Ethiopia & $(0.00)$ & Moldova, Republic of & $(0.111)$ & United States & $(0.00)$ \\
\hline Finland & $(0.00)$ & Mongolia & $(0.00)$ & Uruguay & $(0.00)$ \\
\hline France & $(0.45)$ & Namibia & $(0.00)$ & Venezuela & $(0.2)$ \\
\hline Gabon & $(0.00)$ & Netherlands & $(0.053)$ & Yemen & $(0.071)$ \\
\hline Germany & $(0.071)$ & New Zealand & $(0.00)$ & Zimbabwe & $(0.25)$ \\
\hline Ghana & $(0.00)$ & Nicaragua & $(0.3)$ & & \\
\hline
\end{tabular}

Notes: Unbalanced panel. Average assassinations per country in parenthesis. Countries based on specification (4) in Table 1 


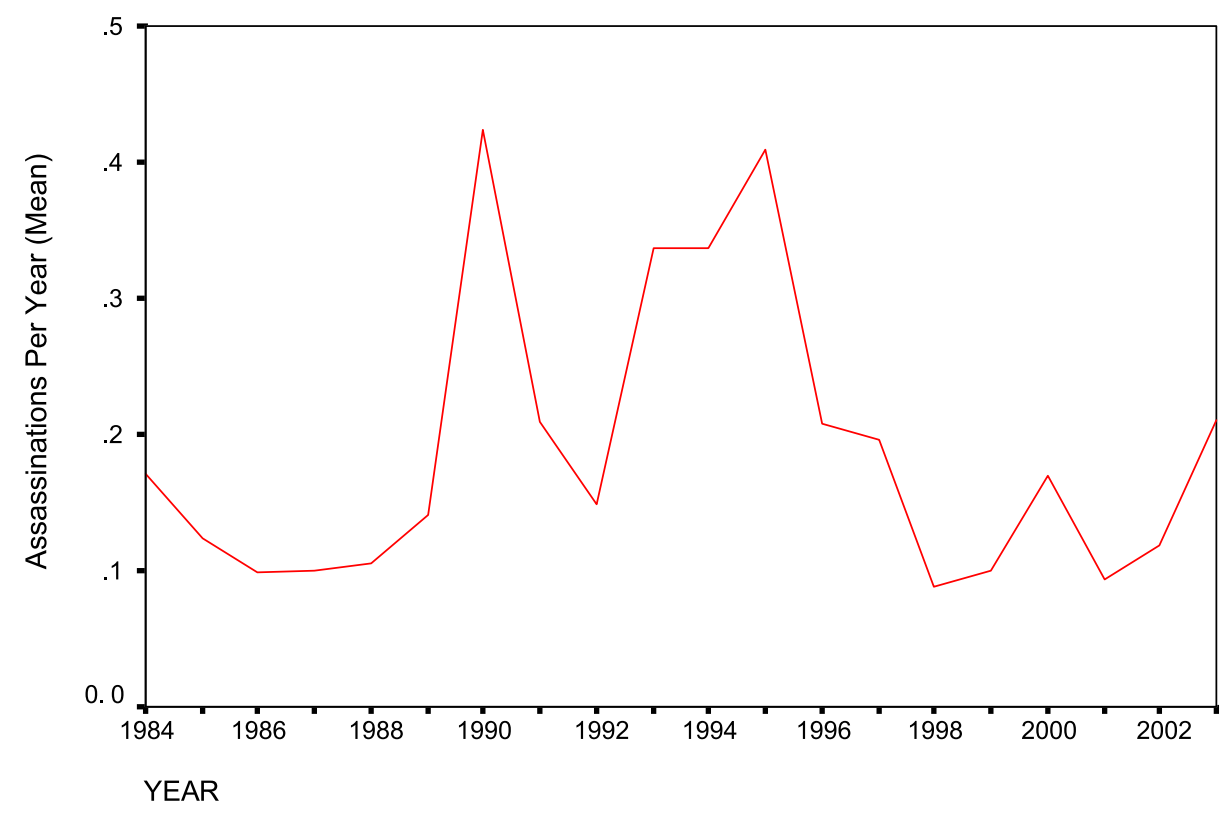

Fig. A.1 Assassinations per year (mean over all countries) 

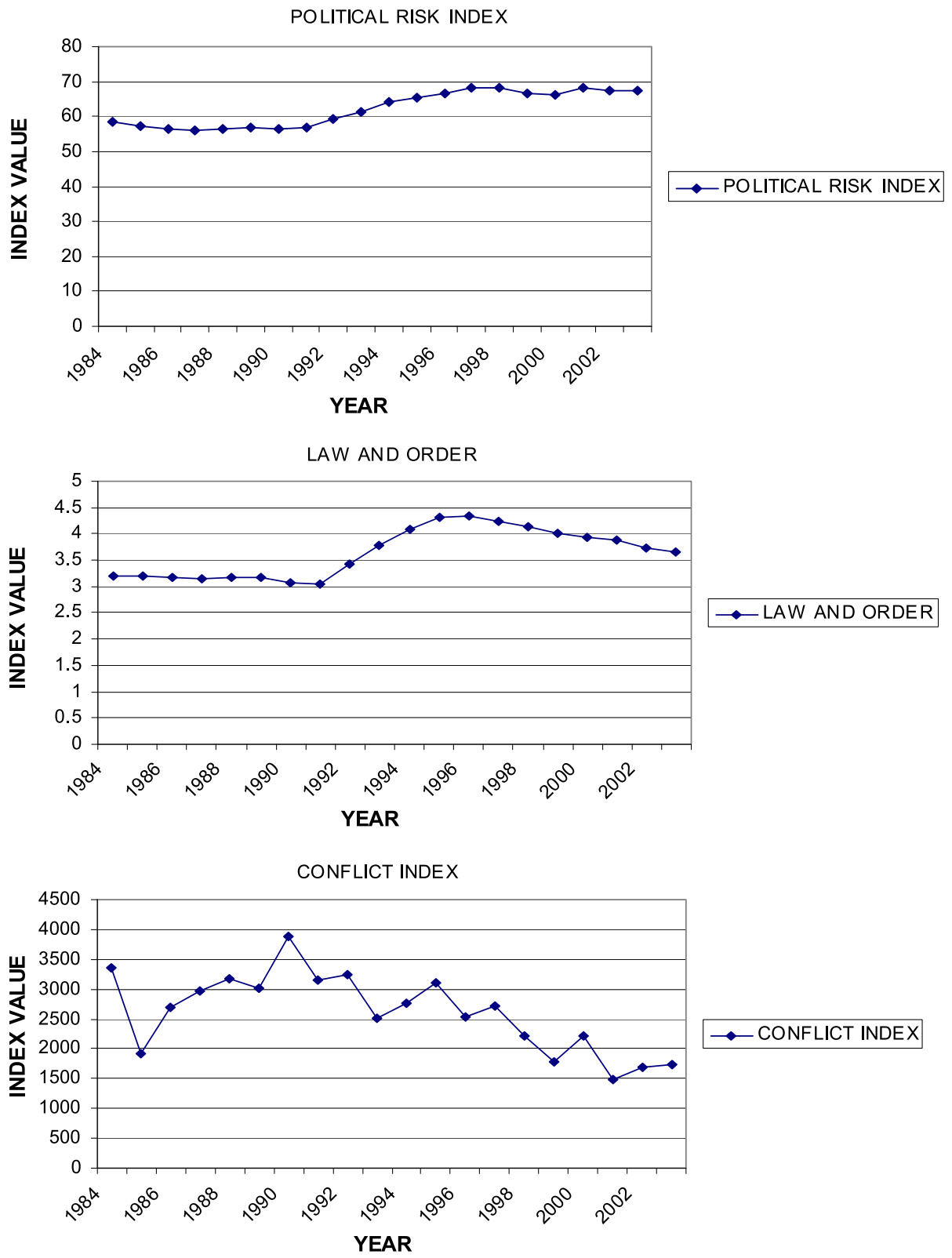

Fig. A.2 Key independent variables per year (mean) 


\section{References}

Adler, F., Mueller, G. O. W., \& Laufer, W. S. (2006). Criminology. New York: McGraw-Hill.

Alesina, A., \& Perotti, R. (1996). Income distribution, political instability, and investment. European Economic Review, 40, 1203-1228.

Alper, N. O., \& Hellman, D. A. (2006). Economics of crime: theory and practice. New York: Pearson Custom Publishing.

Barkan, S. E. (2005). Criminology: a sociological understanding. Upper Saddle River: Prentice Hall.

Bates, R. H., Greif, A., Levi, M., Rosenthal, J. L., \& Weingast, B. (1998). Analytic narratives. Princeton: Princeton University Press.

Becker, G. S. (1968). Crime and punishment: an economic approach. Journal of Political Economy, 76, 497529.

Becker, G. S. (1974). Essays in the economics of crime and punishment. New York: National Bureau of Economic Research.

Becker, G. S., \& Murphy, K. M. (2000). Social economics: market behavior in a social environment. Cambridge: Belknap/Harvard Press.

Beyer, M. (2003). Secret service. New York: Children's Press.

Bondeson, J. (2005). Blood on the snow: the killing of Olof Palme. Ithaca: Cornell University Press.

Brunetti, A., \& Weder, B. (2003). A free press is bad news for corruption. Journal of Public Economics, 87, 1801-1824.

Cameron, S. (1988). The economics of crime deterrence: a survey of theory and evidence. Kyklos, 41, 301323.

Christensen, C. (2004). Political victims and media focus: the killings of Laurent Kabila, Zoran Djinjic, Anna Lindh and Pim Fortuyn. Journal of Crime, Conflict and the Media, 1, 23-40.

Cook, P. J., \& Goss, K. A. (1996). A selective review of the social-contagion literature (Working paper). Sanford Institute of Policy Studies, Duke University.

Demandt, A. (Ed.) (2000). Das Attentat in der Geschichte. Augsburg: Bechtermünz.

Deriabin, P. (1984). Watchdogs of terror: Russian bodyguards from the tsars to the commissars. New Rochelle: Arlington House.

Deriabin, P., \& Bagley, T. H. (1990). K.G.B.: Masters of the Soviet Union. New York: Hippocrene.

Diamond, J. (1997). Guns, germs, and steel. New York: W.W. Northon \& Co., Inc.

DiJulius, III J. R. (2003). Secret service: hidden systems that deliver unforgettable customer service. New York: AMACOM

Dilip, B., \& Ashok, R. (1985). The great betrayal: assassination of Indira Gandhi. Amsterdam: Stosius Inc.

Downs, A. (1957). An economic theory of democracy. New York: Harper and Row.

Duffy, J. P., \& Ricci, V. L. (1992). Target Hitler: the plots to kill Adolf Hitler. Westpoint: Praeger.

Enders, W., \& Sandler, T. (2006). The political economy of terrorism. Cambridge: Cambridge University Press.

Engerman, S. L., \& Sokoloff, K. L. (1997). Factor endowments, institutions and differential paths of growth among new world economies. In S. Haber (Ed.), How Latin America fell behind. Stanford: Stanford University Press.

Feierabend, I. K., Feierabend, R. L., Nesvold, B. A., \& Jaggar, F. M. (1971). Political violence and assassination: a cross-national assessment. In W. J. Crotty (Ed.), Assassinations and the political order (pp. 54-140). New York: Harper and Row.

Fest, J. C. (1963). Das Gesicht des Dritten Reiches. Munich and Zurich: Piper.

Fetzer, J. H. (2000). Experts speak out on the death of John F. Kennedy. Peru: Catfeet Press.

Frank, K. (2002). Indira: the life of Indira Nehru Gandhi. New York: Houghton Mifflin.

Frey, B. S. (2004). Dealing with terrorism: stick or carrot? Cheltenham: Edward Elgar Publishing.

Frey, B. S. (2007a). Politicians are overprotected and isolated. In Vox, 24 August.

Frey, B. S. (2007b). Why kill politicians? A rational choice analysis of political assassinations (Working Paper No. 324). Institute for Empirical Research in Economics, University of Zurich.

Frey, B. S. (2011). Tullock challenges: happiness, revolutions, and democracy. Public Choice, 148, $269-281$.

Gisevius, H. B. (1998). To the bitter end: an insider's account of the plot to kill Hitler, 1933-1945. New York: Da Capo Press.

Glaeser, E. L. (2006). The political economy of warfare (Discussion Paper No. 2125). Harvard Institute of Economic Research.

Graber, G. S. (1982). History of the SS. The most terrifying story of the century. New York: McKay.

Hall, A. R., Rudebusch, G. D., \& Wilcox, D. W. (1996). Judging instrument relevance in instrumental variable estimation. International Economic Review, 37, 283-298.

Hamerow, T. S. (1997). On the road to the wolf's lair: German resistance to Hitler. Cambridge: Harvard University Press. 
Hirshleifer, D., \& Shumway, T. (2003). Good day sunshine: stock returns and the weather. The Journal of Finance, 58, 1009-1032.

Hoffmann, P. (1980). Hitler's personal security: protecting the Führer, 1921-1945. New York: Da Capo Press.

Höhne, H. (1979). Der Orden unter dem Totenkopf. Die Geschichte der SS. Munich: Bertelsmann.

Hudson, M. (2000). Assassination. Thrupp: Sutton Publishing.

Iqbal, Z., \& Zorn, C. (2006). Sic semper tyrannis? Power, repression, and assassination since the second world war. The Journal of Politics, 68, 489-501.

Iqbal, Z., \& Zorn, C. (2008). The political consequences of assassination. The Journal of Conflict Resolution, 52, 385-400.

Jones, B. F., \& Olken, B. A. (2009). Hit or miss? The effect of assassinations on institutions and war. American Economic Journal: Macroeconomics, 1(2), 55-87.

Kellerhoff, S. F. (2003). Attentäter. Mit einer Kugel die Welt verändern. Köln: Böhlau Verlag.

Kershaw, I. (2000). Hitler. 1936-1945: Nemesis. London: Allan Lane and Penguin Press.

Kurrild-Klitgaard, P. (2000). The constitutional economics of autocratic succession. Public Choice, 103, 6384.

Landes, D. S. (1998). The wealth and poverty of nations: why some are so rich and some so poor. New York: Norton.

La Porta, R., Lopez-de-Silanes, F., Shleifer, A., \& Vishny, R. (1999). The quality of government. Journal of Law, Economics, \& Organization, 15, 222-278.

Laucella, L. (1999). Assassination: the politics of murder. New York: McGraw-Hill.

Ludwig, J., \& Kling, J. R. (2006). Is crime contagious? (NBER Working Paper No. 12409). National Bureau of Economic Research.

Manski, C. F. (1993). Identification of endogenous social effects: the reflection problem. Review of Economic Studies, 60, 531-542.

Manski, C. F. (2000). Economic analysis of social interactions. Journal of Economic Perspectives, 14, 115136.

Melanson, P. H., \& Stevens, P. F. (2005). The secret service: the hidden history of an enigmatic agency. New York: Carroll and Graff.

Mitchell, T. D., Carter, T. R., Jones, P. D., Hulme, M., \& New, M. (2004). A comprehensive set of highresolution grids of monthly climate for Europe and the globe: the observed record (1901-2000) and 16 scenarios (2001-2100) (Working Paper 55). Tyndall Centre for Climate Change Research. University of East Anglia, UK.

Nicolle, D. (1995). The Janissaries. Oxford: Osprey Publishing.

Reiner, R. (2002). Media made criminality. The representation of crime in the mass media. Oxford handbook of criminology. Oxford: Oxford University Press.

Roll, R. W. (1992). Weather. In P. Newman, M. Milgate \& J. Eatwell (Eds.), The new Palgrave dictionary of money and finance. London: Macmillan Press.

Sachs, J. D. (2000). Tropical underdevelopment (NBER Working Paper, No. 8119).

Sargan, J. D. (1958). The estimation of economic relationships using instrumental variables. Econometrica, 26, 393-411.

Sarin, R. (1990). The assassination of Indira Gandhi. London: Penguin.

Schaltegger, C. A., \& Torgler, B. (2007). Government accountability and fiscal discipline: a panel analysis with Swiss data. Journal of Public Economics, 91, 117-140.

Schmalleger, F. (2004). Criminology today: an integrative introduction. Upper Saddle River: Prentice Hall.

Schumpeter, J. A. (1942). Capitalism, socialism and democracy. New York: Harper.

Siegel, L. J. (2005). Criminology. Toronto: Thomson Wadsworth Publishing.

Siegel, L. J. (2007). Criminology: the core. Toronto: Thomson Wadsworth Publishing.

Statman, D. (2004). Targeted killing. Theoretical inquiries in law (online edition). url:http://www.bepress. com/til/default/vol5/iss1/art7.

Tullock, D. (2002). Undemocratic governments. Kyklos, 55, 247-264.

Uthmann von, J. (2004). Attentat-Mord mit gutem Gewissen. Bern: Siedler.

Warren, E., et al. (1964). Report of the president's commission on the assassination of President John F. Kennedy. Washington: United States Government Printing Office.

Wilkinson, D. Y. (1976). Social structure and assassination behavior: she sociology of political murder. Cambridge: Schenkman.

Wintrobe, R. (2006). Rational extremism. The political economy of radicalism. Cambridge: Cambridge University Press.

Woolf, G. (2006). Et tu, Brute? The murder of Caesar and political assassination. London: Profile Books.

Zussman, A., \& Zussman, N. (2006). Assassination: evaluating the effectiveness of an Israeli counterterrorism policy using stock market data. Journal of Economic Perspectives, 20, 193-202. 